\title{
Karakteristik Campuran AC-WC dengan Penambahan Limbah Plastik Low Density Polyethylene (LDPE)
}

\author{
Bustamin Abd. Razak ${ }^{1, a}$ dan Andi Erdiansa ${ }^{1, b}$ \\ ${ }^{1}$ Dosen Jurusan Teknik Sipil Politeknik Negeri Ujung Pandang \\ a bustamin.ar@poliupg.ac.id \\ berdiansaandi@yahoo.co.id
}

\begin{abstract}
This study aims to determine the effect of using plastic waste Low Density polyethylene ( LDPE ) on the characteristics of a mixture of AC- WC . This study used five plastic content variation is $1 \%, 2 \%, 3 \%, 4 \%$, and $5 \%$ to determine the characteristics of the AC- WC. The method used in this study is a test that aims marshall know the characteristics , the performance of the mixture, and the optimum level of use of asphalt in the mix AC- WC . The results showed that the characteristic value $\mathrm{AC}$ - WC that include the percentage of plastic content obtained from the testing of $1 \%-5 \%$ of the optimum bitumen content, if the levels of plastic in bitumen is added, the value of stability, flow, and marshall quotient increase and decrease unstable, while the value of VFB and the density increases, and the value of VIM and VMA decreases .
\end{abstract}

Keywords-LDPE; Marshall; AC-WC

\section{Pendahuluan}

Banyaknya jalan raya yang mengalami kerusakan, sebagian besar diakibatkan oleh konstruksi jalan yang tidak sesuai dengan pemakaian, ditambah lagi dengan tingginya curah hujan di Indonesia. Banyak jalan raya khususnya jalan lintas provinsi yang mengalami kerusakan baik kecil, menengah maupun berat sehingga diperlukan penanganan yang serius tentang kerusakan jalan yang ada di Indonesia.

Perencanaan yang baik merupakan langkah awal dalam usaha untuk mencapai hasil yang diinginkan. Pekerjaan yang melibatkan material-material tertentu tetapi tidak terencana dengan baik akan menimbulkan beberapa kesulitan dan masalah seperti kualitas pekerjaan yang tidak sesuai dengan spesifikasi atau persyaratan yang diharapkan. Untuk daerah tropis sperti Indonesia jenis aspal yang sering digunakan adalah jenis aspal keras Pen 60/70 dimana titik lelehnya berkisar antara 48-58. Selain itu, Indonesia yang beriklim tropis menjadi faktor penyebab kerusakan dini seperti hancurnya lapisan permukaan jalan aspal akibat perubahan cuaca yang sangat cepat maupun beban yang melewati jalan tersebut, karena untuk waktu dan daerah tertentu, suhu jalan bisa mencapai $70^{\circ} \mathrm{C}$ yang menyebabkan aspal menjadi meleleh sehingga aspal yang melekat pada agregat terpisah. Pemisahan agregat dan aspal ini (bleeding) yang merupakan penyebab aspal begitu mudah tererosi akibat kikisan air atau tidak tahannya beban yang begitu berat saat melintas diatas aspal jalan raya. Aspal dibuat dari distilat terakhir dari 
minyak bumi yang mengandung rantai karbon, oksigen dan hidrogen serta sedikit sulfur dan nitrogen.

Dari kandungan senyawa yang ada pada aspal sangat memungkinkan diperkuat ketahananya melalui reaksi dengan bahan polimer sistesis maupun polimer alam. Selain dapat mengoptimalkan karakteristik aspal penggunaan plastik sebagai bahan tambah pada aspal juga dapat mengurangi kerusakan lingkungan karena sebagaimana yang diketahui, plastik yang mulai digunakan sekitar 50 tahun yang silam, kini telah menjadi barang yang tidak terpisahkan dalam kehidupan manusia. Diperkirakan ada 500 juta sampai 1 milyar plastik low density polyethylene (LDPE) digunakan penduduk dunia dalam satu tahun. Konsumsi berlebih terhadap plastik pun mengakibatkan jumlah sampah plastik yang besar sementara waktu plastik untuk terdekomposisi (terurai) dengan sempurna diperkirakan membutuhkan waktu 100 hingga 500 tahun lamanya.

\section{Metode Penelitian}

Penelitian dilaksanakan di Laboratorium Bahan Jalan Jurusan Teknik Sipil Politeknik Negeri Ujung Pandang Jl. Perintis Kemerdekaan Km 10 Tamalanrea, Makassar. Dimulai pada tanggal 14 Mei 2012 sampai bulan Oktober 2012.dimana secara garis besar metode Penelitian ini trgambar dalam bagan alir berikut.

\section{Hasil dan Pembahasan}

\section{A. Hasil Pemeriksaan Karakteristik Material}

\section{Agregat kasar}

Hasil pemeriksaan karakteristik agregat kasar untuk rancangan campuran laston lapis aus adalah sebagai berikut:

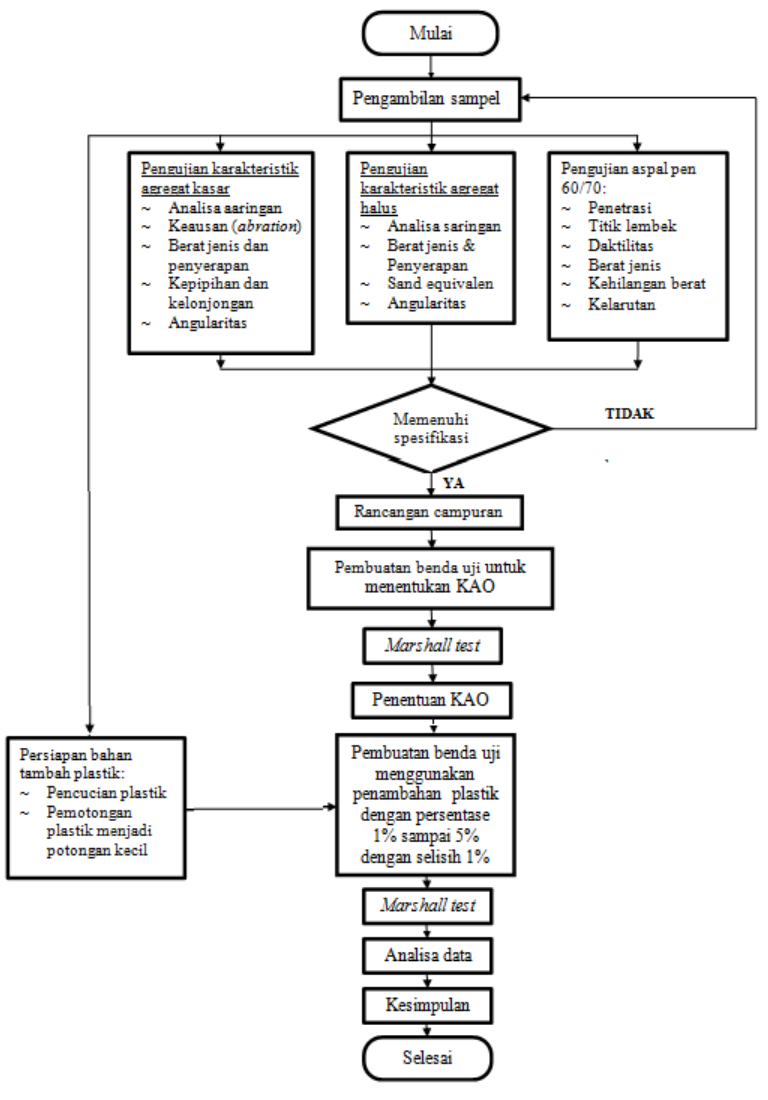

Gambar 1. Bagan Alir Penelitian

Tabel 1. Rekapitulasi Hasil Pemeriksaan Agregat Kasar

\begin{tabular}{|l||c||c||c|c||c||}
\hline \multicolumn{1}{|c|}{$\begin{array}{c}\text { Jenis } \\
\text { pemeriksaan }\end{array}$} & Metode & Hasil & Spesifikasi & \multirow{2}{*}{ Satuan } \\
\cline { 5 - 6 } & & Min & Max & \\
\hline \hline Gradasi & SNI 03-4142-1996 & Tabel & - & - & $\%$ \\
\hline Angularitas & & 93,19 & & & $\%$ \\
\hline $\begin{array}{l}\text { Abrasi dengan } \\
\text { mesin los angeles }\end{array}$ & SNI 2417:2008 & 19,10 & - & 30 & $\%$ \\
\hline Berat jenis dan & & & & & \\
penyerapan & & & & & \\
1. Bulk & SNI 1969:2008 & 2,58 & & 3 & $\%$ \\
2. SSD & 2,62 & & & \\
3. Apparent & & 2,69 & & & \\
4. Penyerapan & & 1,53 & & & \\
\hline
\end{tabular}


Tabel 2. Rekapitulasi Hasil Pemeriksaan Agregat Kasar (Batu Pecah 0,5-1)

\begin{tabular}{|c|c|c|c|c|c|}
\hline \multirow{2}{*}{$\begin{array}{c}\text { Jenis } \\
\text { pemeriksaan }\end{array}$} & \multirow{2}{*}{ Metode } & \multirow{2}{*}{ Hasil } & \multicolumn{2}{|c|}{ Spesifikasi } & \multirow{2}{*}{ Satuan } \\
\hline & & & Min & Max & \\
\hline Gradasi & SNI 03-4142-1996 & \begin{tabular}{|l|} 
Lampiran \\
\end{tabular} & $\therefore$ & "- & $\%$ \\
\hline Angularitas & & 97.83 & & & \\
\hline $\begin{array}{l}\text { Berat jenis dan } \\
\text { penyerapan } \\
\text { 1. Bulk } \\
\text { 2. SSD } \\
\text { 3. Apparent } \\
\text { 4. Penyerapan }\end{array}$ & SNI 1969:2008 & $\begin{array}{l}2.55 \\
2.60 \\
2.69 \\
1.92\end{array}$ & & 3 & $\%$ \\
\hline
\end{tabular}

\section{Abu batu}

Hasil pemeriksaan karakteristik abu batu untuk rancangan campuran laston lapis aus adalah sebagai berikut:

Tabel 3. Rekapitulasi Hasil Pemeriksaan Agregat Halus (Abu Batu)

\begin{tabular}{|c|c|c|c|c|c|}
\hline \multirow{2}{*}{$\begin{array}{c}\text { Jenis } \\
\text { pemeriksaan }\end{array}$} & \multirow{2}{*}{ Metode } & \multirow{2}{*}{ Hasil } & \multicolumn{2}{|c|}{ Spesifikasi } & \multirow{2}{*}{ Satuan } \\
\hline & & & Min & Max & \\
\hline Gradasi & SNI 03-4428-1997 & Lampiran & - & - & $\%$ \\
\hline $\begin{array}{l}\text { Berat jenis dan } \\
\text { penyerapan } \\
\text { 1) Bulk } \\
\text { 2) SSD } \\
\text { 3) Apparent } \\
\text { 4) Penyerapan }\end{array}$ & & $\begin{array}{l}2.72 \\
2.74 \\
2.79 \\
0.93\end{array}$ & & 3 & $\%$ \\
\hline Sand equivalent & AASHTO T-176 & 77.63 & 50 & & $\%$ \\
\hline
\end{tabular}

\section{Bahan pengikat (aspal)}

Hasil pemeriksaan karakteristik aspal penetrasi 60/70 untuk rancangan campuran AC-WC adalah sebagai berikut:

Tabel 4. Hasil Pemeriksaan Karakteristik Aspal

\begin{tabular}{|c|c|c|c|c|c|}
\hline \multirow{2}{*}{ Jenis pemeriksaan } & \multirow{2}{*}{ Metode } & \multirow{2}{*}{ Hasil } & \multicolumn{2}{|c|}{ Spesifikasi } & \multirow{2}{*}{ Satuan } \\
\hline & & & Min & Max & \\
\hline Penetrasi $\left(25^{\circ} \mathrm{C}, 5\right.$ detik $)$ & $\begin{array}{c}\text { SNI } \\
06-2456-1991\end{array}$ & 68.5 & 60 & 70 & $\mathrm{Mm}$ \\
\hline Titik lembek, ${ }^{\circ} \mathrm{C}$ & $\begin{array}{c}\text { SNI } \\
06-2434-1991\end{array}$ & 48.1 & 48 & 58 & ${ }^{\circ} \mathrm{C}$ \\
\hline $\begin{array}{l}\text { Kelekatan agregat } \\
\text { terhadap aspal }\end{array}$ & $\begin{array}{c}\text { SNI } \\
03-2439-1991\end{array}$ & 100,0 & 95 & - & $\%$ \\
\hline Berat jenis & $\begin{array}{c}\text { SNI } \\
06-2441-1991\end{array}$ & 1.041 & 1 & - & $\mathrm{gr} / \mathrm{ml}$ \\
\hline Daktilitas, $25^{\circ} \mathrm{C}$ & $\begin{array}{c}\text { SNI } \\
06-2432-1991\end{array}$ & 117.5 & 100 & - & $\mathrm{Cm}$ \\
\hline Kelarutan dalam CCL4 & ASTM D5546 & 99.03 & 99 & - & $\%$ \\
\hline \multicolumn{6}{|c|}{$\begin{array}{l}\text { Pengujian setelah TFOT } \\
\end{array}$} \\
\hline Kehilangan berat & $\begin{array}{c}\text { SNI } \\
06-2441-1991\end{array}$ & 0.3 & - & 1 & $\%$ \\
\hline Daktilitas, $25^{\circ} \mathrm{C}$ & $\begin{array}{c}\text { SNI } \\
06-2432-1991\end{array}$ & 106.5 & 100 & - & $\mathrm{Cm}$ \\
\hline Penetrasi pada suhu $25^{\circ} \mathrm{C}$ & $\begin{array}{c}\text { SNI } \\
06-2456-1991 \\
\end{array}$ & 54.8 & 54 & - & $\%$ \\
\hline
\end{tabular}

\section{B. Hasil Rancangan AC-WC}

\section{Rancangan $\mathrm{AC}-\mathrm{WC}$ agregat original}

Tabel 5. Gradasi Gabungan Agregat

\begin{tabular}{|c|c|c|c|c|c|c|c|c|c|c|c|}
\hline \multicolumn{2}{|c|}{ Saringan } & \multicolumn{4}{|c|}{ Komulatif lolos } & \multicolumn{5}{|c|}{$\begin{array}{c}\text { Penggabungan anggregat } \\
\text { AC-WC (halus) }\end{array}$} & \multirow{3}{*}{ Spek. } \\
\hline \multirow[t]{2}{*}{ ASTM } & \multirow[t]{2}{*}{$(\mathrm{mm})$} & \multirow{2}{*}{$\begin{array}{l}\text { Agregat } \\
(1-2)\end{array}$} & \multirow{2}{*}{$\begin{array}{l}\text { Agregat } \\
(0,5-1)\end{array}$} & \multirow{2}{*}{$\begin{array}{l}\text { Abu } \\
\text { batu }\end{array}$} & \multirow[t]{2}{*}{ Filler } & $\begin{array}{c}\text { Agregat } \\
(1-2)\end{array}$ & $\begin{array}{c}\text { Agregat } \\
(0,5-1)\end{array}$ & $\begin{array}{l}\text { Abu } \\
\text { batu }\end{array}$ & Filler & \multirow[t]{2}{*}{ Total } & \\
\hline & & & & & & $14 \%$ & $26 \%$ & $58 \%$ & $2 \%$ & & \\
\hline $3 / 4^{\prime \prime}$ & 19 & 100.00 & 100.00 & 100.00 & 100 & 14.00 & 26.00 & 58.00 & 2.0 & 100.00 & 100 \\
\hline $1 / 2^{\prime \prime}$ & 12.5 & 34.06 & 100.00 & 100.00 & 100 & 4.77 & 26.00 & 58.00 & 2.0 & 90.77 & $90-100$ \\
\hline $3 / 8^{\prime \prime}$ & 9.5 & 10.64 & 96.35 & 100.00 & 100 & 1.49 & 25.05 & 58.00 & 2.0 & 86.54 & $72-90$ \\
\hline$\# 4$ & 4.75 & 1.05 & 21.75 & 100.00 & 100 & 0.15 & 5.66 & 58.00 & 2.0 & 65.80 & $54-69$ \\
\hline$\# 8$ & 2.36 & 0.37 & 0.30 & 81.82 & 100 & 0.05 & 0.08 & 47.46 & 2.0 & 49.59 & $39.1-53$ \\
\hline$\# 16$ & 1.18 & 0.34 & 0.22 & 60.79 & 100 & 0.05 & 0.06 & 35.26 & 2.0 & 37.36 & $31.6-40$ \\
\hline$\# 30$ & 0.6 & 0.30 & 0.20 & 42.02 & 100 & 0.04 & 0.05 & 24.37 & 2.0 & 26.46 & $23.1-30$ \\
\hline$\# 50$ & 0.3 & 0.25 & 0.19 & 24.32 & 100 & 0.04 & 0.05 & 14.10 & 2.0 & 16.19 & $15.5-22$ \\
\hline$\# 100$ & 0.15 & 0.22 & 0.15 & 13.14 & 100 & 0.03 & 0.04 & 7.62 & 2.0 & 9.69 & $9-15$ \\
\hline$\# 200$ & 0.75 & 0.15 & 0.11 & 4.45 & 100 & 0.02 & 0.03 & 2.58 & 2.0 & 4.63 & $4-10$ \\
\hline
\end{tabular}

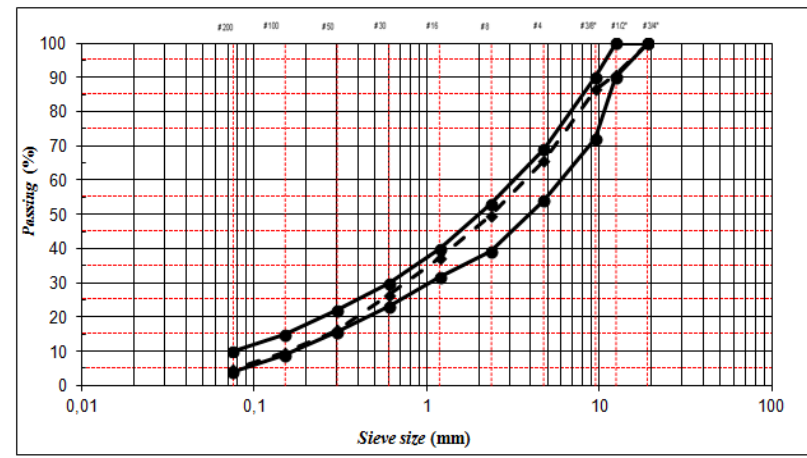

Gambar 2. Grafik Penggabungan Agregat Gabungan Bersih

Perkiraan awal kadar aspal rancangan dapat diperoleh dari rumus:

$$
\begin{gathered}
\mathrm{Pb}=0,035(\% \mathrm{CA})+0,045(\% \mathrm{FA})+0,18(\% \text { filler }) \\
+ \text { konstanta }
\end{gathered}
$$

Dimana:

$\mathrm{Pb}=$ Kadar aspal perkiraan/kadar aspal tengah (ideal), persen terhadap berat campuran

$\mathrm{CA}=$ Persen agregat tertahan saringan No.8

$\mathrm{FA}=$ Persen agregat lolos saringan No. 8 dan tertahan No. 200

$\mathrm{FF}=$ Fine Filler lolos saringan 200

Nilai konstanta untuk laston adalah $0,5-1,0$

$$
\begin{aligned}
\mathrm{Pb} & =0,035(50.41)+0,045(44.95)+0,18(4.63)+0,5 \\
& =5,22 \rightarrow 5.5 \%
\end{aligned}
$$

Sehingga digunakan kadar aspal $4,5 \% ; 5 \% ; 5,5 \% ; 6 \%$; $6,5 \% ; 7 \%$. 
Kemudian dari kadar aspal tersebut dibuat masingmasing tiga buah benda uji (briket) untuk enam kadar aspal yang berbeda, dimana berat total campuran untuk satu buah benda uji adalah 1200 gram. Dengan kebutuhan agregat sebagai berikut:

Tabel 6. Daftar Timbangan Agregat

\begin{tabular}{|c|c|c|c|c|c|c|c|}
\hline \multicolumn{2}{|c|}{ Kadar aspal rencana } & $4.5 \%$ & $5.0 \%$ & $5.5 \%$ & $6.0 \%$ & $6.5 \%$ & $7.0 \%$ \\
\hline \multicolumn{2}{|l|}{ Total campuran } & 1200 & 1200 & 1200 & 1200 & 1200 & 1200 \\
\hline \multicolumn{2}{|l|}{ Kebutuha aspal } & 54.0 & 60.0 & 66.0 & 72.0 & 78.0 & 84.0 \\
\hline \multicolumn{2}{|l|}{ Berat agregat } & 1146.0 & 1140.0 & 1134.0 & 1128.0 & 1122.0 & 1116.0 \\
\hline Agregat (1-2) & $14.00 \%$ & 160.4 & 159.6 & 158.8 & 157.9 & 157.1 & 156.2 \\
\hline Agregat $(0,5-1)$ & $26.00 \%$ & 298.0 & 296.4 & 294.8 & 291.7 & 291.7 & 290.2 \\
\hline Abu batu & $58.00 \%$ & 664.7 & 661.2 & 657.7 & 650.8 & 650.8 & 647.3 \\
\hline Filler & $\begin{array}{r}2.00 \% \\
100.0 \%\end{array}$ & 22.9 & 22.8 & 22.7 & 22.4 & 22.4 & 22.3 \\
\hline $\begin{array}{l}\text { Berat komulatif } \\
\text { Agregat (1-2) }\end{array}$ & agregat & 160.4 & 159.6 & 158.8 & 157.9 & 157.1 & 156.2 \\
\hline Agregat $(0,5-1)$ & & 458.4 & 456.0 & 453.6 & 449.6 & 448.8 & 446.4 \\
\hline Abu batu & & 1123.1 & 1117.2 & 1111.3 & 1100.4 & 1099.6 & 1093.7 \\
\hline Filler & & 1146.0 & 1140.0 & 1134.0 & 1122.8 & 1122.0 & 1116.0 \\
\hline
\end{tabular}

Dari hasil pengetesan aspal beton (laston) ACWC yang dibuat dalam bentuk benda uji dengan alat Marshall, diperoleh hasil seperti pada tabel analisa hasil pemeriksaan marshall, tetapi sebelum masuk analisa tabel hasil pemeriksaan marshall, terlebih dahulu harus dihitung:

Tabel 7. Barat Jenis dan Penyerapan Bahan

\begin{tabular}{||l||c||c||c||c|}
\hline \hline \multirow{2}{*}{ Material } & $\begin{array}{c}\text { Berat jenis } \\
\text { bulk }\end{array}$ & $\begin{array}{c}\text { Berat jenis } \\
\text { semu }\end{array}$ & $\begin{array}{c}\text { Berat jenis } \\
\text { efektif }\end{array}$ & $\begin{array}{c}\text { Komposisi terhadap } \\
\text { total agregat (\%) }\end{array}$ \\
\cline { 3 - 5 } & $\mathrm{A}$ & $\mathrm{B}$ & $\mathrm{C}=(\mathrm{A}+\mathrm{B}) / 2$ & $\mathrm{D}$ \\
\hline \hline Agregat 1-2 & 2,58 & 2,69 & 2,64 & 14 \\
\hline Agregat $0,5-1$ & 2,55 & 2,69 & 2,62 & 26 \\
\hline Abu Batu & 2,72 & 2,79 & 2,75 & 58 \\
\hline Filler & 3,14 & 3,14 & 3,14 & 2 \\
\hline Aspal & \multicolumn{3}{|c|}{1,040} \\
\hline
\end{tabular}

2. Rancangan $\mathrm{AC}-\mathrm{WC}$ dengan bahan tambah plastik

Kadar aspal efektif campuran AC-WC yang dibuat untuk penelitian adalah $6,31 \%$ dari berat campuran yang diperoleh dari hasil pengujian sebelumnya, selanjutnya membuat benda uji dengan kadar aspal efektif yang ditambahkan dengan plastik, dimana persentase penambahan plastik $1 \% ; 2 \% ; 3 \% ; 4 \% ; 5 \%$ dari berat aspal efektif sebanyak tiga benda uji setiap kadar plastik kemudian dirata-ratakan.
Tabel 8. Daftar timbangan agregat dengan menggunakan plastik

\begin{tabular}{|c|c|c|c|c|c|c|c|}
\hline \multicolumn{2}{|c|}{ Kadar plastik rencana } & $0.0 \%$ & $1.0 \%$ & $2.0 \%$ & $3.0 \%$ & $4.0 \%$ & $5.0 \%$ \\
\hline \multirow{2}{*}{\multicolumn{2}{|c|}{$\begin{array}{l}\text { Total campuran } \\
\text { kadar aspal efektif } \\
(6.31 \% \times 1200)\end{array}$}} & 1200 & 1200 & 1200 & 1200 & 1200 & 1200 \\
\hline & & 75.7 & 75.7 & 75.7 & 75.7 & 75.7 & 75.7 \\
\hline \multicolumn{2}{|c|}{ Kebutuhan aspal } & 75.7 & 74.9 & 74.2 & 73.4 & 72.7 & 71.9 \\
\hline \multicolumn{2}{|c|}{ Kebutuhan plastik } & 0.0 & 0.8 & 1.5 & 2.3 & 3.0 & 3.8 \\
\hline \multicolumn{2}{|l|}{ Berat agregat } & 1124.3 & 1124.3 & 1124.3 & 1124.3 & 1124.3 & 1124.3 \\
\hline Agregat (1-2) & $14.00 \%$ & 157.4 & 157.4 & 157.4 & 157.4 & 157.4 & 157.4 \\
\hline Agregat $(0,5-1)$ & $26.00 \%$ & 292.3 & 292.3 & 292.3 & 292.3 & 292.3 & 292.3 \\
\hline Abu batu & $58.00 \%$ & 652.1 & 652.1 & 652.1 & 652.1 & 652.1 & 652.1 \\
\hline Filler & $\begin{array}{r}2.00 \% \\
100.0 \%\end{array}$ & 22.5 & 22.5 & 22.5 & 22.5 & 22.5 & 22.5 \\
\hline \multicolumn{8}{|c|}{ Berat komulatif agregat } \\
\hline Agregat $(0,5-1)$ & & 449.7 & 449.7 & 449.7 & 449.7 & 449.7 & 449.7 \\
\hline Abu batu & & 1101.8 & 1101.8 & 1101.8 & 1101.8 & 1101.8 & 1101.8 \\
\hline Filler & & 1124.3 & 1124.3 & 1124.3 & 1124.3 & 1124.3 & 1124.3 \\
\hline
\end{tabular}

Hasil karakteristiknya sebagai berikut:

Tabel 9. Rekapitulasi hasil parameter-parameter marshall test

\begin{tabular}{||c||c||c||c||c||c||c||c||}
\hline \hline $\begin{array}{c}\text { Kadar } \\
\text { Plastik (\%) }\end{array}$ & $\begin{array}{c}\text { VIM } \\
(\%)\end{array}$ & $\begin{array}{c}\text { VMA } \\
(\%)\end{array}$ & $\begin{array}{c}\text { VFB } \\
(\%)\end{array}$ & $\begin{array}{c}\text { Stabilitas } \\
(\mathrm{kg})\end{array}$ & $\begin{array}{c}\text { Flow } \\
(\mathrm{mm})\end{array}$ & $\begin{array}{c}\text { Kepadatan } \\
\left(\mathrm{gr} / \mathrm{cm}^{2}\right)\end{array}$ & $\begin{array}{c}\text { Koef. marshall } \\
(\mathrm{kg} / \mathrm{mm})\end{array}$ \\
\hline \hline 0.0 & 4.34 & 17.19 & 74.77 & 1811 & 3.48 & 2.35 & 520.46 \\
\hline 1.0 & 4.26 & 17.09 & 75.06 & 2216 & 4.41 & 2.35 & 504.03 \\
\hline 2.0 & 4.04 & 16.84 & 76.01 & 1946 & 4.06 & 2.36 & 477.67 \\
\hline 3.0 & 3.82 & 16.61 & 77.06 & 2061 & 3.93 & 2.36 & 524.87 \\
\hline 4.0 & 3.75 & 16.52 & 77.32 & 1690 & 4.43 & 2.37 & 385.88 \\
\hline 5.0 & 3.81 & 16.52 & 76.92 & 2350 & 3.90 & 2.36 & 606.26 \\
\hline
\end{tabular}

Setelah mendapatkan hasil pengujian marshall hasilnya digambarkan dalam grafik hubungan antara kadar aspal ditambah plastik dengan parameterparameter yang telah dihitung.

\section{Pembahasan}

\section{Hubungan kadar plastik dan stabilitas}

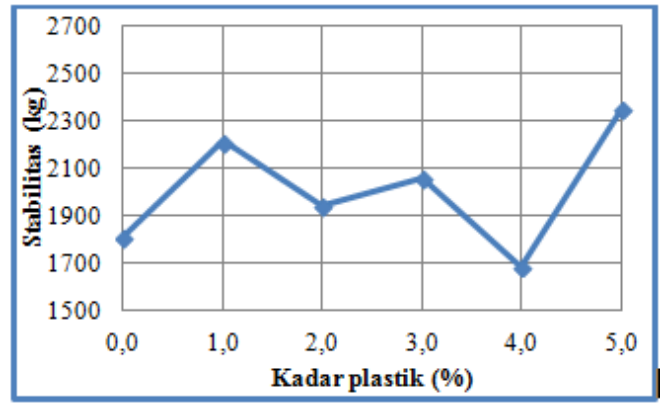

Gambar 3.Hubungan antara kadar plastik dengan nilai stabilitas 
Dari diagram di atas menunjukkan bahwa nilai stabilitas dengan menggunakan persentase plastik jenis LDPE sebagai bahan tambah pada rancangan campuran AC-WC memgalami kenaikan dan penurunan dari stabilitas tanpa menggunakan bahan tambah. Nilai stabilitas tertinggi terdapat pada kadar plastik 5\% dan terendah dapat dilihat pada kadar 4\%.

Pemgaruh penambahan plastik pada aspal terhadap nilai kadar aspal efektif, yaitu untuk aspal murni (plastik $0 \%$, plastik $1 \%, 2 \%, 3 \%, 4 \%$ dan $5 \%$ berturut-turut sebesar $6.25 \%, 6.18 \%, 6.12 \%, 6.06 \%, 5.99 \%$ dari berat total campuran. Pada stabilitas, campuran kekuatannya meningkat (stabilitas naik) kecuali pada campuran kadar aspal $6.06 \%$ (kadar plastik 4\%). Pada campuran aspal murni (plastik 0\%) nilai stabilitasnya $1811 \mathrm{~kg}$, sedangkan pada campuran kadar aspal 5.99\% (kadar plastik 5\%) memiliki nilai stabilitas $2350 \mathrm{~kg}$ mengalami kenaikan stabilitas yang sangat tinggi, sehingga dapat dikatatakan bahwa dalam pengujian ini, penambahan plastik mempengaruhi nilai stabilitas.

Hal ini disebabkan karena plastik mengisi rongga antar butiran agregat sehingga ronga antar butiran agregat menjadi kecil dan rapat, di samping itu campuran memiliki kadar aspal yang rendah dibandingkan dengan campuran aspal murni (plastik 0\%) sehimgga mencukupi untuk mengikat antar butir agregat.

2. Hubungan Kadar Plastik dengn Flow

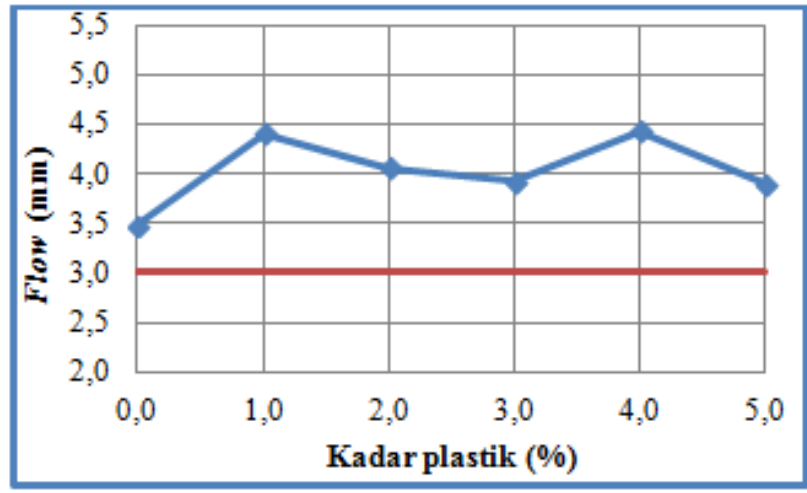

Gambar 4. Hubungan antara kadar plastik dengan Flow

Dari diagram diatas menunjukkan bahwa nilai tertinggi flow dengan menggunakan persentase plastik sebagai bahan tambah pada rancangan campuran $\mathrm{AC}-$ WC berada pada kadar persentase 4\% dari hasil pengujian yang dilakukan. Nilai flow terendah dapat dilihat pada kadar plastik 3\% dan tidak lebih rendah dari nilai flow pada aspal murni (plastik $0 \%$ ).

Penambahan plastik pada campuran aspal mempengaruhi nilai flow. Hal ini dapat dilihat pada campuran aspal murni (plastik 0\%) dengan nilai flow 3,48 mm dan campuran kadar aspal 5,99\% (plastik 5\%) dengan nilai 3,99 mm mengalami kenaikan flow apabila ditambah dengan plastik, meskipun hasilnya mengalami kenaikan dan penurunan, tetapi nilainya tidak melewati nilai flow pada campuran aspal murni (plastik $0 \%$ ).

Hal ini disebabkan karena penambahan kadar aspal akan membuat flow menjadi meningkat, sedangkan pada penelitian ini, apabila dilakukan penambahan plastik maka nilai kadar aspalnya akan berkurang karena berpatokan pada kadar aspal efektif. Jadi dapat dikatakan bahwa plastik dapat besifat sebagai aspal sehingga menyebabkan kenaikan nilai flow.

3. Hubungan kadar plastik dan marshall quotient (MQ)

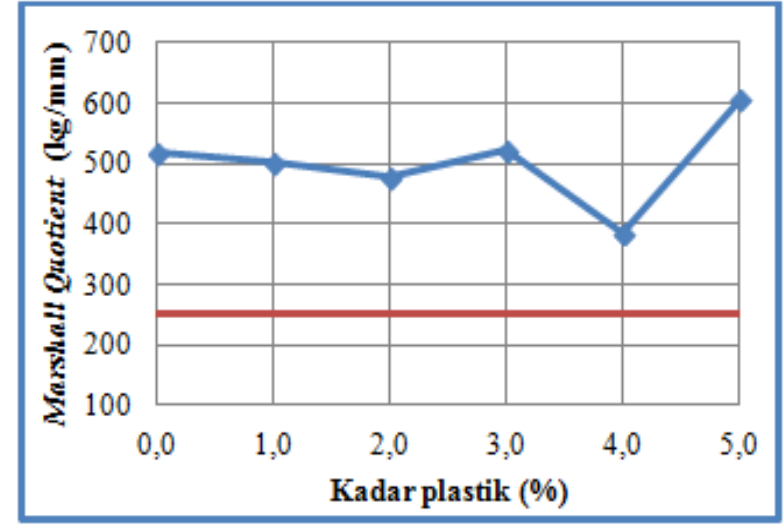

Gambar 5. Hubungan antara kadar plastik dengan Nilai MQ

Dari diagram diatas menunjukkan bahwa nilai Marshall Quotient menggunakan persentase plastik sebagai bahan tambah pada rancangan campuran ACWC mengalami kenaikan dan penurunan dari hasil pengujian yang dilakukan. Namun demikian penambahan plastik dari persentase $1 \%$ sampai $5 \%$ memenuhi syarat spesifikasi yaitu minimum $250 \mathrm{~kg} / \mathrm{mm}$.

Penambahan plastik pada campuran aspal mempengaruhi nilai Marshall Quotient. Hal ini dapat dilihat pada campuran aspal murni (plastik 0\%) dengan nilai Marshall Quotient $520.46 \mathrm{~kg} / \mathrm{mm}$ dan campuran kadar aspal 5,99\% (plastik 5\%) dengan nilai Marshall 
Quotient $606.26 \mathrm{~kg} / \mathrm{mm}$ mengalami kenaikan apabila ditambah dengan plastik, sedangkan hasil pada kadar aspal 6,25\% (palstik 1\%), 6,18\% (plastik 2\%) dan kadar aspal 6,06\% (plastik 4\%) mengalami penurunan yang lebih rendah dari nilai campuran aspal murni (plastik $0 \%)$.

Semakin tinggi nilai kadar aspal maka nilai Marshall Quotient semakin menurun, artinya semakin bertambahnya kadar aspal akan menyebabkan campuran menjadi getas, sedangkan penambahan plastik pada aspal menyebabkan peningkatan dan penurunan nilai Marshall Quotient, jadi dalam pengujian ini dpat dikatakan bahwa penambahan plastik pada campuran akan mempengaruhi nilai Marshall Quotient.

\section{Hubungan kadar plastik dengan void in mix (VIM)}

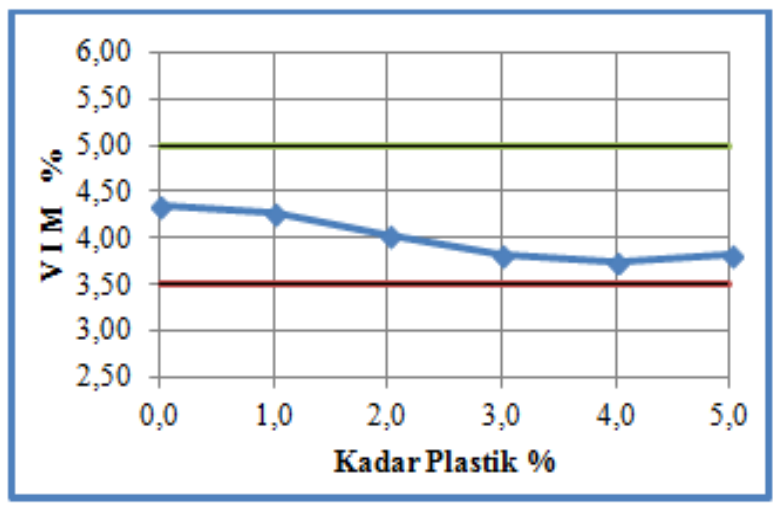

Gambar 6. Hubungan antara kadar plastik dengan Nilai VIM

Dari diagram diatas menunjukan bahwa nilai VIM campuran AC-WC dengan persentase plastik mengalami penurunan nilai VIM. Penurunan dimulai pada saat penambahan kadar plastik 1\% sampai 5\%, Nilai VIM tertinggi dapat dilihat pada kadar aspal murni (plastik 0\%) dan nilai VIM terendah dapat dilihat pada kadar plastik 4\%. Pada campuran aspal murni (plastik 0\%) nilai VIM yaitu 4,34\%, sedangkan pada campuran kadar aspal $5.99 \%$ (kadar plastik 5\%) memiliki nilai VIM $3,81 \%$ mengalami penurunan, sehingga dapat dikatatakan bahwa dalam pengujian ini, penambahan plastik mempengaruhi nilai VIM.

Nilai VIM berpengaruh terhadap keawetan lapis perkerasan, semakin tinggi nilai VIM menunjukkan semakin besar rongga dalam campuran sehingga campuran bersifat pourous. Sedangkan dalam penelitian ini, nilai VIM yang diperoleh semakin rendah sehingga menunjukkan semakin kecil rongga dalam campuran.
Hal ini mengakibatkan campuran menjadi rapat sehingga air dan udara sulit memasuki rongga-rongga dalam campuran yang menyebabkan aspal tereduksi.

5. Hubungan kadar plastik dan void in mineral agregate (VMA)

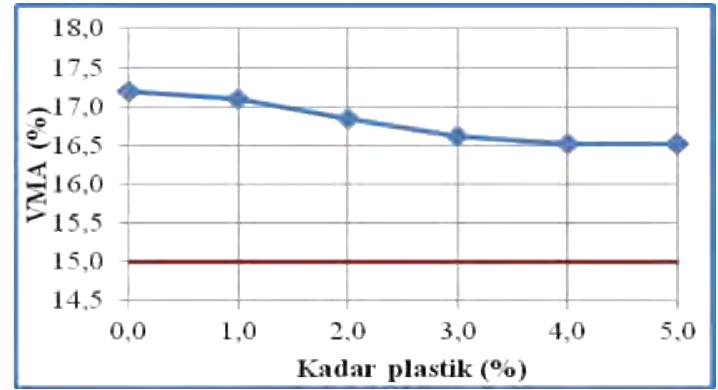

Gambar 7. Hubungan antara kadar plastik dengan Nilai VMA

Dari diagram diatas menunjukan bahwa nilai VMA pada campuran AC-WC dengan menggunakan plastik mengalami penurunan pada saat penambahan mulai $1 \%$ sampai 5\%. Nilai VMA tertinggi diperoleh pada kadar plastik 0\% dengan nilai VMA $17,19 \%$ dan terendah terdapat pada kadar plastik 5\% dengan nilai VMA $16,52 \%$.

Penambahan plastik pada campuran aspal mempengaruhi nilai VMA. Agregat bergaradasi baik atau bergradasi rapat memberikan rongga antar butiran agregat (VMA) yang kecil. Hal ini disebabkan lapisan plastik telah menyelimuti agregat dan menutup sebagian besar rongga antara butiran.

6. Hubungan kadar plastik dan void fill bitumen (VFB)

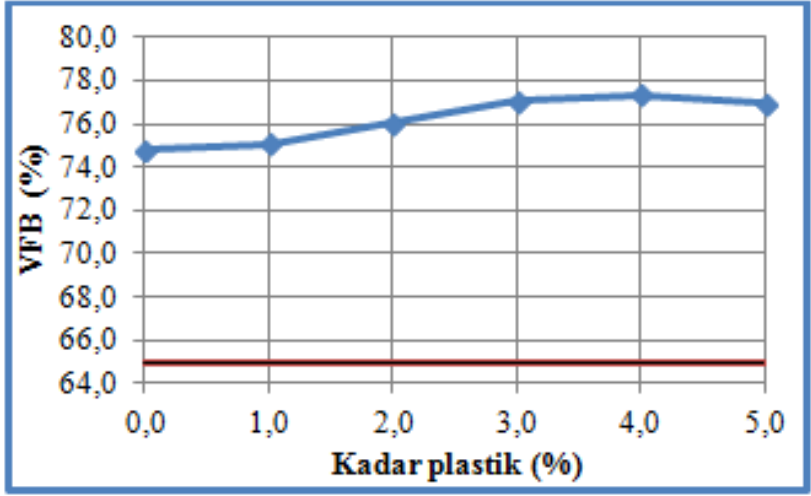

Gambar 8. Hubungan antara kadar plastik dengan Nilai VFB

Dari diagram diatas menunjukkan bahwa nilai VFB pada campuran $\mathrm{AC}-\mathrm{WC}$ dengan menggunakan plastik 
mengalami peningkatan pada saat penambahan persentase kadar plastik dari 1\% sampai 5\%. Nilai VFB terendah diperoleh pada kadar plastik $0 \%$, dan nilai VFB tertinggi terjadi pada kadar 4\%.

Pada campuran aspal murni (plastik 0\%) nilai VFB $74.77 \%$, sedangkan pada campuran kadar aspal $5.99 \%$ (kadar plastik 5\%) memiliki nilai VFB 76,92\% mengalami kenaikan, sehingga dapat dikatatakan bahwa dalam pengujian ini, penambahan plastik mempengaruhi nilai VFB.

Hal ini disebabkan karena penambahan persentase kadar plastik yang berada dalam aspal mengakibatkan rongga yang berada dalam VMA yang terisi akan semakin bertambah, sehingga mengakibatkan rongga terisi aspal yang bercampur plastik bertambah.

\section{Kesimpulan}

Dari hasil penelitian yang dilakukan di laboratorium tentang "Tinjauan Karakteristik Campuran AC-WC Akibat Penambahan Limbah Plastik Low Density Polyethylene (LDPE)" maka dapat ditarik kesimpulan bahwa penambahan limbah plastik Low Density Polyethylene (LDPE) pada karakteristik campuran ACWC dapat menambah nilai volumetrik campuran ACWC dimana nilai VIM dan VMA mengalami penurunan, sedangkan pada nilai VFB mengalami kenaikan.
Sedangkan berdasarkan sifat fisik campuran, penambahan limbah plastik mengalami kenaikan dan penurunan yang tidak stabil, sehingga pengaruh limbah plastik terhadap sifat fisik campuran AC-WC tidak jelas.

\section{Ucapan Terima Kasih}

Kami mengucapkan banyak terima kasih kepada pihak jurusan teknik sipil PNUP yang telah memberikan izin penggunaan laboratorium serta peralatan yang ada dalam penelitian ini.

\section{Daftar Pustaka}

[1] Departemen Pekerjaan Umum. 2010.” Spesifikasi Umum Bidang Jalan dan Jembatan". Direktorat Jenderal Bina Marga.

[2] Haryanto,2010. "Polimer Termoplastic dan Termosetting", (online) (http://www.chem-is-try.org. diakses 29 November 2011).

[3] Restu, Henry MS.dan N. Antonius .2011. “ Karakteristik Campuran AC-WC dengan Bahan Tambah Plastik”. Makassar.

[4] S. Silvia. 2003 "Beton Aspal Campuran Panas," Jakarta: granit.

[5] Thamrin. 2011. "Limbah Plastik Dapat Memperkuat Aspal", (Online), (http://MedanPunya.com, diakses 29 November 2011) 